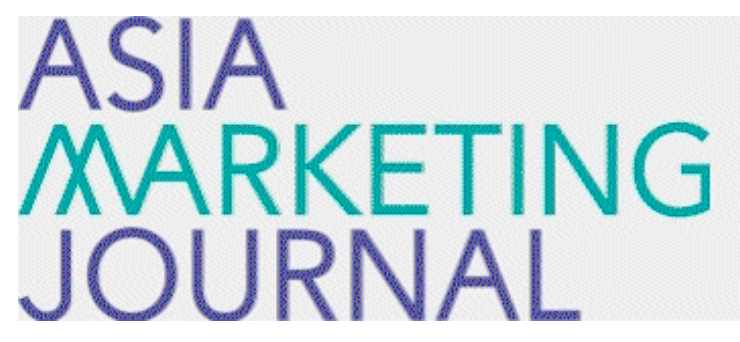

ASIA MARKETING JOURNAL

Volume 9 | Issue 3

Article 5

10-30-2007

\title{
금호렌터카의 고객만족 경영
}

Young Won $\mathrm{Ha}$

Kyung Do Park

Jin Yong Park

Follow this and additional works at: https://amj.kma.re.kr/journal

Part of the Marketing Commons

\section{Recommended Citation}

Ha, Young Won; Park, Kyung Do; and Park, Jin Yong (2007) "금호렌터카의 고 객만족 경영," Asia Marketing Journal: Vol. 9 : Iss. 3 , Article 5.

Available at: https://doi.org/10.53728/2765-6500.1201

This Article is brought to you for free and open access by Asia Marketing Journal. It has been accepted for inclusion in Asia Marketing Journal by an authorized editor of Asia Marketing Journal. 


\title{
금호렌터카의 고객만족 경영
}

\section{Customer Satisfaction Management of Kumho Rent-A Car}

\author{
하 영 원(Ha, Young-Won) ${ }^{*}$ \\ 박 경 도(Park, Kyung-Do)** \\ 박 진 용(Park, Jin Yong) ${ }^{* * *}$
}

본 사례는 국내 렌터카 시장에서 시장점유율과 매출액에서 최고의 위치에 있는 금호렌터카의 성공 요인에 대해 분석하였다. 금호렌터카가 렌터카 시장에서 대표기업으로 부상한 주요 성공요인은 고객 만족을 중시하는 경영에 있음에 주목하여 금호렌터카의 고객만족 경영방식을 상세히 고찰하고 시사 점을 제시하였다. 분석을 위해 금호렌터카의 고객만족 경영을 첫째, 고객의 욕구를 팍악하는 것을 중 심으로 하는 고객관계관리 측면과, 둘째 서비스 품질통제를 위한 서비스 프로세스 관리의 측면으로 나누어 살펴보았다.

핵심개념: 금호, 렌터카, 고객만족, 서비스, 품질, 고객관리

\section{I. 서 론}

렌터카는 고객에게 유상으로 자동차를 대여하 는 사업이다. 1917년 미국의 Walter Jacob \& John Hertz 합작회사가 선보인 Hertz system이 렌터카 사업의 시초로 알려져 있다. 우리나라의 경우 1975년부터 렌터카 사업이 도입되기 시작 하여, 1988년 서울 올림픽을 전후로 렌터카 사 업이 신고제로 전환되면서 정부의 정책사업으
로서 렌터카 사업이 활성화 되었다. 우리나라 렌터카 시장규모는 2006년 차량대수 기준으로 130 만대를 기록하고 있다. 여가를 중요하게 생 각하는 고객의 변화와 주5일제의 도입은 렌터 카 시장의 지속적인 성장을 가능하게 하고 있 다. 이러한 성장 속에 렌터카 사업의 경쟁도 매 우 치열하게 전개되고 있다.

렌터카 시장에서 시장점유율에 대한 기준은 차량의 보유대수를 기준으로 이루어지고 있는 데, 이 중에서 시장점유율 1 위 기업인 금호랜터

\footnotetext{
* 서강대학교 (ywha@sogang.ac.kr)

** 서강대학교(kyungdo@sogang.ac.kr)

*** 건국대학교 (jypark65@konkuk.ac.kr)
} 
카는 약 $21 \%$ 의 시장점유율을 기록하고 있다 (〈그림 1) 참고). 이는 2 위 업체와 $5 \%$ 이상 차 이로 업계의 수위를 지키는 기록이다. 1990년부 터 본격적으로 렌터카 시장에 진출한 금호렌터 카는 다른 경쟁자에 비해서 높은 경쟁력을 갖 는 것으로 평가되고 있다. 금호렌터카가 최근 수상한 각종 수상내역으로도 금호렌터카가 업 계에서 차지하는 위상을 짐작하게 하는 대목이 다. 금호렌터카는 렌터카 부문에서 수년간 각종 브랜드 대상, 신뢰기업 대상 및 기업 대상을 수 상하고 있으며, 서비스 품질 1위 및 고객 만족 도 1 위의 자리를 지키고 있다. 2006년 한 해에 만 19건의 수상실적을 기록하고 있고 2002년부 터 현재까지 60건이 넘는 수상실적을 기록했다. 이와 같은 성장의 여세를 몰아서 금호렌터카 는 국내시장에서의 사업 확장과 서비스 품질의 고도화를 통해서 국내시장에서의 확고한 최고 렌터카 기업이라는 위상을 강화하는 것은 물론 중국을 비롯한 해외시장으로 진출을 의욕적으 로 추진하고 있다. 금호렌터카는 2011년 아시아
최고의 렌터카 기업이 된다는 목표를 향해 매 진하고 있다.

본 사례는 금호렌터카가 지금의 위치에 있을 수 있었던 핵심적 요소로서 그들의 고객만족 경영에 초점을 맞추고 있다. 시장점유율 1 위는 물론 지속적인 매출의 성장과 회원수의 증가와 같은 경영 성과는 금호렌터카가 고객만족을 최 우선으로 하는 경영을 실행하고 있기 때문이라 고 판단된다. 이하에서는 먼저 고객만족의 개넘 과 고객만족 경영의 중요성을 살펴보고 금호렌 터카의 고객만족 경영 방식을 제시된 고객만족 관련 연구의 틀에 맞추어 검토하고 시사점을 제시한다.

\section{II. 고객만족경영}

고객만족경영의 의미를 확인하기 위하여 경영 적 관점에서 고객만족을 위한 개념체계를 제시

〈그림 1〉 국내 렌터카 시장 규모와 시장점유율

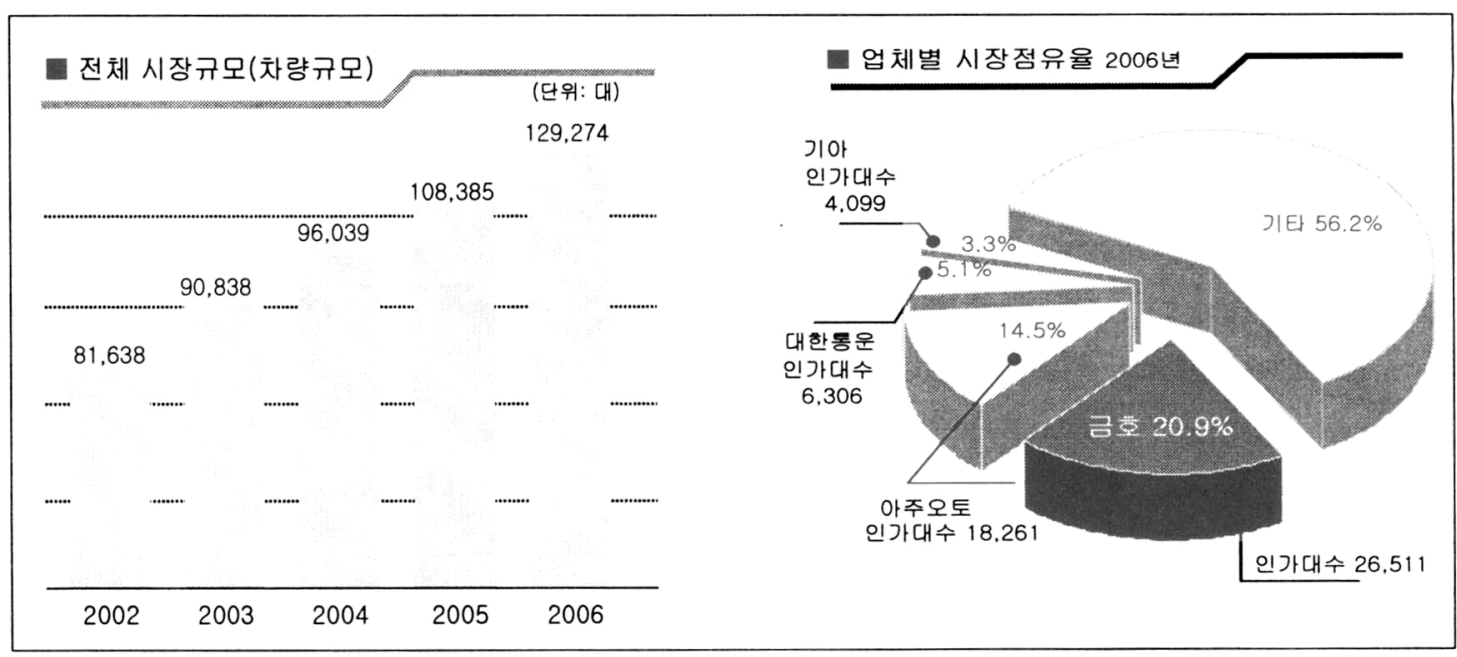


하고자 한다. 본 사례 분석을 위하여 근간으로 삼고 있는 사업 수월성 모델은 고객만족 경영 을 프로세스 관점에서 해석하고 있으며 장기 적 관점의 고객관리를 강조하고 있다. 이하에 서는 고객만족의 중요성을 확인하고 사업 수 월성 모델을 중심으로 고객만족경영에 대해 검토하였다.

\section{1 고객만족의 중요성}

마케팅에서 가장 중요한 핵심어를 한 가지만 정하라고 한다면 단연 '고객만족'이 꼽힐 것이 다. 마케팅이 추구하는 궁극적인 목표가 고객 의 만족을 제고함으로써 기업의 이익을 확보하 는 것이기 때문이다. 그러므로 성공하는 기업 들은 고객의 욕구를 정확히 파악하고 이에 대 한 적절한 편익을 제공할 수 있는 특징을 가지 고 있다.

학문적으로 고객만족에 대한 연구는 마케팅이 학문으로 자리매김한 역사와 함께 한다. 최근의 연구들을 살펴보면 고객만족은 기업이 제공하 는 제품과 서비스에 대해서 일정 기간 동안의 구매와 소비 경험에 비추어 내려지는 고객의
전반적인 평가라고 설명된다(Anderson, Fornell, and Mazvancheryl 2004. Fornell 1992). 이는 고객만족에서 고객과 기업의 상호작용의 중요 성이 강조되고 있으며, 단기적인 거래보다는 장 기적인 거래를 통해서 형성된 고객만족이 기업 에 기여하는 바가 더 크다는 것을 반영하고 있 다. 따라서 고객만족은 기업의 전랴 측면에서도 중요한 우선순위에 놓이며, 장기적인 수익과 시 장가치 창출을 가능하게 한다는 점에서 그 중 요성을 확인할 수 있다(Fornell, Mithas, Morgeson III, and Krishnan 2006, Gruca and Rego 2005).

\section{2 사업 수월성 모형}

이처럼 기업의 고객만족의 문제는 고객관계 관리의 문제(Piercy 1998. Sheth and Parvatiya 1995)와 고객만족을 성공적으로 유지 관리할 수 있는 프로세스의 관리의 두 측면에 초점이 맞추어 지고 있다(Kanji 1998).

$\mathrm{Kanji}(1998)$ 는 자신의 사업수월성 모형에서 프로세스 관리를 통한 사업 수월성(business excellence)이 달성되는 과정을 제시하였다. 사 업 수월성의 달성을 위한 가장 중요한 원천으

〈그림 2〉 Kanji (1998)의 사업 수월성(business excellence) 모델

\begin{tabular}{|c|ccc|}
\hline 기초 & \multicolumn{1}{c|}{ 윈리 } & 핵심 개념 & 고업 \\
& 고객 감동 & 초점 & 수월성 \\
리더쉽 & 실제에 기초한 관리 & 프로세스 성과 & \\
& 인적자원에 기초한 관리 & 인적자원 성과 \\
& 지속적인 개선 & 개선 운화 정착
\end{tabular}


로 리더십을 제시하고 있는데 최고경영층의 고 객만족 경영에 대한 의지가 이에 해당한다. 원 리와 핵심개념은 각각 연관된 네 가지 개념으 로 구성되어 있는데 고객 감동과 고객 초점, 객 관적 근거에 의한 관리와 프로세스에 의한 성 과, 인적자원 중심과 인적자원에 의한 성과. 그 리고 지속적인 개선과, 개선의 문화 정착을 통 해서 사업의 수월성이 달성됨을 제시하였다.

고객만족경영의 프로세스 역시 Kanji의 사업 수월성 모델에서 제시된 흐름을 통해 달성이 가능하다. 고객만족경영의 프로세스와 사업 수 월성 모델은 고객만족을 최우선으로 둔다는 점 에서 그 특징을 공유하고 있으며, 고객만족을 통해서 탁월한 기업 역랑을 확보한다는 점에서 추구하는 목표가 동일하다. 또한 방법적인 차원 에서도 객관적이며 정량화된 서비스를 제공하 여야 하며, 이를 조직 전반이 공유하는 기제를 마련하고 고객 만족을 위한 지속적인 서비스 개선의 문화가 정착되어야 비로소 고객만족경 영이 구체화될 수 있다는 점도 고객만족경영의 프로세스와 사업수월성모델의 유사한 측면이라 할 수 있다.

\section{3 고객만족경영}

고개만족경영은 기업의 최종 목적을 고객만족 에 두고 고객만족향상을 위해 지속적으로 노력 하는 것을 의미한다(이유재 2000), 고객만족경 영의 실천을 위해서 고객관계관리 프로그램을 확보하여야 한다. 최적 고객 포트폴리오의 구성 은 물론, 차별화된 고객 서비스의 창출이 요구 된다. 고객의 의견을 수렴하고 체계화하는 절차 가 마련되어야 하며 수렴된 의견은 정량화되어
조직이 공유할 수 있는 형태로 재구성되어야 한다. 이를 기반으로 새롭게 창출되는 고객 서 비스는 고객만족을 위한 노력과 방법으로 구체 화되어 기업 전체의 구성원과 조직이 공유하는 문화로 형성된다.

고객만족경영을 위해서는 두 가지 요소를 고 려하여야 한다. 하나는 고객관계관리이며, 다른 하나는 고객서비스에 대한 프로세스 관리이다. 고객관계관리를 통해서 도출된 새로운 아이디 어를 체계화 시킨 서비스를 제공하는 것이 가 장 효과적이라는 점에서 고객관계관리와 서비 스 프로세스 관리는 분리된 개념이 아니고 상 호보완적 개념이다.

기존의 연구에서는 고객관계관리를 위한 몇 가지 지침을 제공하고 있다(Peppers and Rogers 1995). 우선 고객을 보는 시각의 변화가 필요하 다. 고객의 생애가치(customer life value)를 고 려하여 장기적인 동반자 관계가 형성되어야 한 다(Berger and Nasr 1998, Haenlein, Kaplan, and Schoder 2006). 다음으로는 고객과의 원할 한 의사소통이다. 다양한 의사소통이 있겠지만 고객의 의견을 수렴하고 수렴된 의견이 서비스 에 반영된 결과가 다시 고객에게 전달되는 양 방향적 의사소통이 가능하여야 한다. 마케팅 성 과지표는 시장점유율은 물론 고객점유율 개넘 이 도입되어야 한다. 고객의 생애가치 중에서 일정한 비중을 차지하는 것이 중요하며 이를 늘려가는 것이다. 마지막으로 차별화의 초점을 제품에서 고객으로 전환하는 것이다. 강하게 형 성된 고객과의 밀착이 중요하므로 기업에 이익 을 제공하는 장기적인 고객에 대한 관리가 수 반되어야 한다. 고객관계관리의 구체적인 실천 방안으로는 고객포트폴리오의 관리. 고객욕구의 
이해, 차별화된 서비스의 제공. 고객 불평의 관 리, 판매 후 고객관리 등이 제시되었다(이유재 2000).

고객 프로세스의 관리는 전사적 품질관리 차 원에서 다양하게 논의 되고 있다. 즉 고객만족 경영을 고객 옥구에 기초한 품질개선활동을 전 개하는 경영방식으로 간주하는 것이다(강부식, 김태한, 박상찬 2001). 이러한 논의에 의하면 품질관리의 기본적인 관점은 고객중심의 높은 품질성과를 유지하기 위한 접근방법이어야 한 다는 것이다(Flynn, Schroeder, and Sakakibara 1994). 따라서 제품과 서비스에 대한 고객의 만 족도를 고객의 입장에서 평가하는 것은 물론 이에 기초하여 품질 개선활동을 전개하는 경영 방식으로 고객프로세스 관리의 특징을 설명하 고 있다. 이러한 관점에서는 조직의 구성원 즉 최고경영층에서 일선 서비스 제공자에 이르기 까지 고객의 의견(소리)에 초점을 두고 체계화 된 관리 과정에 따라 서비스를 통제할 수 있다 고 주장하고 있다(Dijkstra and van der $\mathrm{Bij}$ 2002). 고객의 옥구에 대해 어떻게 대응할 것인 가를 모든 조직구성원이 방안을 찾아가는 과정 을 시스템화하는 과정이 고객에게 제공되는 서 비스를 통제하고 개선하게 된다.

고객만족경영 관점에서 최고경영자의 의지는 고객만족경영을 위한 필수조건이다. 최고경영자 는 배경, 심리적 툭성, 그리고 역량의 정도에 따라 조직의 성과에 영향을 미친다. 고객만족경 영 역시 최고경영자의 역량에 따라 많은 영향 을 받게 된다. 고객만족경영을 도입하고 추진하 는 측면에서도 중요하며. 전략과 구조를 변화시 켜 성과에 영향을 준다는 측면에서 매우 중요. 하다(Baron 2000).
전사적 품질관리의 성공을 위해서 기존의 연 구들은 조직구성원의 몰입을 강조하고 있다(서 창적, 김재환 2002). 고객에게 제공하는 서비스 품질의 향상과 개선을 위해서는 고객만족에 대 한 조직구성원의 의지와 몰입이 요구된다. 이 를 위해서는 조직구성원에 대한 체계적이고 지 속적인 고윢이 매우 중요하다. 교육은 고객에 대한 정보를 공유하고 개선된 서비스 품질 프 로세스를 이해하고 고객에게 전달하는 데 활용 된다.

\section{III. 금호렌터카의 고객만족 경영}

이미 강조한 것처럼 금호렌터카의 고객만족 경영은 두 가지로 압축할 수 있다. 하나는 고객 의 욕구를 파악하는 것을 중심으로 전개되는 고객관계관리이며. 다른 하나는 서비스품질통제 를 위한 프로세스 관리이다.

\section{1 금호렌터카}

금호렌터카는 2006년 2,400억이 넘는 매출을 기록하고 했다. 최근 연 $40 \%$ 에 육박하는 매출 증가율의 결과였다. 뿐만 아니라 시장점유율 증 가도 두드러지고 있다. 금호렌터카가 이러한 마 케팅 성과는 높은 서비스품질 수준의 유지를 통한 고객만족도 제고에 기반하고 있다. 금호렌 터카 자체적으로 운영하고 있는 고개불만 접수 조사 현황에서도 대여건수대비 $0.016 \%$ 의 낮은 불만율을 기록하고 있으며, 이러한 고객관계 관 리에 기울인 노력은 회원수의 증가로 이어졌다. 
금호렌터카 회원은 2000년 6만3천명에서 2006 년 55 만 5 천명으로 급증한 것으로 나타났다.

\section{2 금호렌터카의 상품구성}

금호렌터카는 상품은 장기대여 상품과 단기대 여 상품으로 구분할 수 있다. 장기대여는 차량 을 직접 구매하지 않고 1 년 이상 필요한 기간 만큼 장기적으로 대여 하여 사용하는 상품을 의미한다. 차량수리, 정비, 사고처리 및 보험 등 모든 차량관리를 금호렌터카가 책임을 지고 서 비스를 수행하기 때문에 고객에게 제공하는 서 비스 수준이 높을 수밖에 없다.

고객의 입장에서는 차량구입에 대한 초기 부 담이 없는 경제적 편익이 있으며, 사고 발생시 보험료 할증에 대한 부담이 없으며, 사고에 대 한 신속한 처리와 사고기간 중의 무상대차서비 스도 받을 수 있다. 순회정비를 통한 정기적인 점검 서비스를 제공하기 때문에 최적의 상태에 서 차량을 이용할 수 있게 된다.

단기상품의 경우 출장이나 여행 등의 목적으 로 단기간(통상 30 일 이내) 차랑을 대여하는 상품을 의미한다. 전국에 100 여 개의 영업망을 가지고 있으며, 국내에서는 금호렌터카가 가장 많은 수의 차량을 보유하고 있다. 공항은 물론 철도 및 호텔과의 연계전략을 통해 고객접점을 늘리고 있다. 차령의 경우 3 년 이내로 제한을 두어 차량노후화에 의한 고객의 불만을 최소화 하고 있다. Hertz와 연계서비스로 해외 예약 서 비스도 가능하다.

추가적으로 고객에게 제공되는 서비스로는. 편도대여서비스, 배반차 서비스, 보험 대차. 차 량손해면책 제도를 제공하고 있다. 편도대여 서
비스를 통해 고객은 임대한 지점이 아닌 다른 지역에서 차량반납이 가능하고, 배반차 서비스 를 활용해서 원하는 곳에서 차량을 받거나 반 납할 수 있다. 보험 대차를 통해서 피해사고 시 차량의 수리기간 동안 손해보험사와 협약된 차 량을 무상으로 지원받을 수 있으며, 일정수수료 지불로 사고 발생시 차량손해 부담을 면책 해 주고 있다.

장단기 대여 상품 이외에도 기사포함 대여 상 품을 운영하고 있다. 기사들은 무사고 경력은 물론 외국어 구사가 가능하고 철저한 서비스 교육에 통해 높은 수준의 서비스를 제공한다.

각각의 상품에 대해서 고객만족 경영의 방식 과 전략은 차이가 있다. 그러나 그 근간은 고객 관계관리와 서비스 품질통제라는 점을 공유하 고 있다.

\section{3 금호렌터카의 고객만족을 위한 고객관계 관리}

\subsection{1 고객욕구의 파악}

고객만족을 위한 고객관계관리의 첫 출발점은 렌터카 고객의 옥구를 파악하는 것이다. 파악된 고객 옥구에 맞추어서 편익을 제공하여야 하기 때문이다. 금호렌터카는 일반적인 렌터카 고객 의 옥구를 관리하고 있다. 고객욕구의 중요성과 평가점수 행렬을 이용하여 고객만족을 위한 우 선과제에 대해 도출하였다. 즉 고객들이 중요하 다고 여기는 옥구와 함께 금호렌터카에 대한 평가를 고려하여 고객만족 제고를 위한 방향을 설정하고 있다.

우선 높은 중요도를 보이는 고객 욕구로는 약 
속의 이행, 신뢰감, 고객응대 등이 확인되었다. 접근 용이성. 예상외 혜택, 본원적인 욕구 등을 그 다음으로 중요하게 평가하였다. 마지막으로 는 물리적 환경, 독창적인 서비스를 중요하다고 지적한 것으로 나타났다.

동시에 고객들은 각각의 욕구 차원에서 금호 렌터카가 제공하는 편익에 대해 평가하였다. 약 속의 이행, 물리적 환경, 고객 응대, 접근 용이 성 등의 항목에 대해서는 금호렌터카에 높은 점수를 부여했으며, 신뢰감과 본원적 옥구에서 는 중간 정도의 평가를, 독창적 서비스와 예상 외 혜택 등에서는 낮은 평가를 내렸다.

중요도와 평가점수를 동시에 고려하여 유지 강화 하여야 할 요소와 중점적으로 개선하여야 할 부분을 도출할 수 있었다. 뿐만 아니라 지속 적으로 유지해야 할 요소와 점진적으로 개선해 야 할 요소를 확인할 수 있었다(〈그림 3〉 참고).

금호렌터카는 고객과의 약속이행, 고객 응대
및 신뢰감 형성을 중심으로 고객만족의 차별성 을 기하는 것은 물론 접근의 용이성, 우수한 물 리적 환경, 본원적인 서비스의 제공을 통해서 고객 서비스 수준을 높일 수 있는 것으로 판단 하였다.

약속의 이행, 신뢰감의 형성은 본질적으로 우 수한 마케팅 프로그램과 연관되어 있다. 동시에 단기적인 거래에서 확보되기 어렵다는 측면에 서 고객과의 장기적 관계형성이 중요하다는 점 을 의미한다. 약속의 이행은 역량의 문제와 연 결되고 신뢰는 호의와 관련되어 있다. 고객과의 관계관리의 핵심은 이처럼 가시화하기 어려운 요소를 체계적으로 관리하여야 하는 문제와 연 결되어 있다.

금호렌터카는 고객과의 관계형성을 위해 구체 적인 고객의 의견에 주목하는 프로그램을 운영 하고 있다. 고객의 의견은 칭찬이든 불평이든 모두 중요한 것이다. 상호작용의 증대는 장기적

〈그림 3〉 렌터카 고객의 욕구 분석 및 금호렌터카가 제공하는 편익

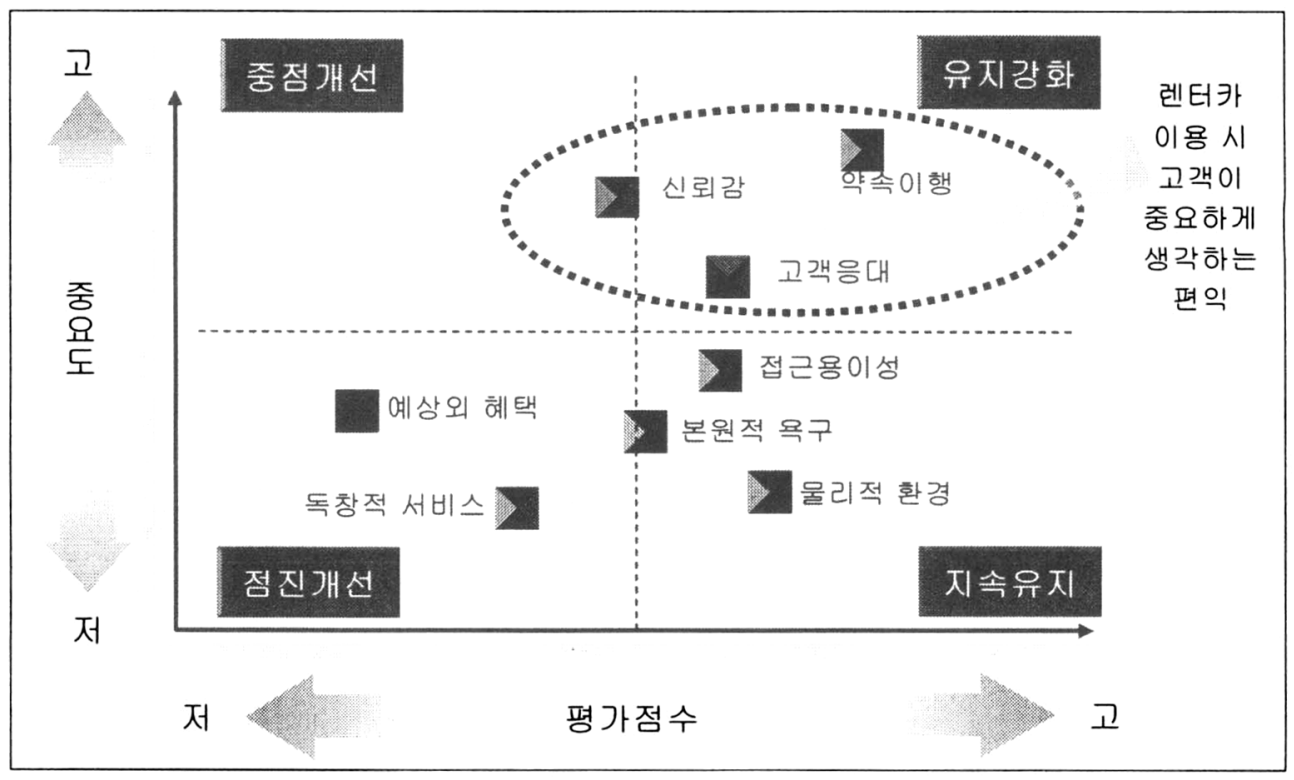


관계형성의 시작임을 물론 마케텅 프로그램의 개선을 고객의 관점에서 재구성할 수 있다는 점에서 그 의미를 찾을 수 있다.

\subsection{2 고객만족 서비스 개선을 위한 VOC 프로그램}

VOC는 고객의 소리(voice of customer)를 의 미한다. 고객만족을 위해서는 고객을 이해하는 것이 중요한데 고객의 소리를 통해서 확보된 고객 의견수렴은 고객이 무엇을 원하고 무엇을 불만족스러워 하는지를 파악하는 중요한 정보 가 된다. 그런데 고객의 의견이 마케팅 프로그 램의 조정에 반영되지 못한다면 그 의미가 축 소될 것이다. 그러므로 고객의 의견을 체계적으 로 데이터로 구축하는 것, 구축된 정보로부터 마케팅 프로그램을 조정하는 프로그램이 개발 되어야 한다. 우선 〈그림 4)는 금호렌터카의 서
비스 향상 및 개발 프로세스를 도식으로 설명 한 것이다.

현장의 불만과 의견에 대한 수렴과 $\mathrm{VOC}$ 를 통해서 접수된 고객의견이 통합되어 관리된다. 확보된 고객의견은 고객만족팀을 통해 관리되 며, 고객만족팀에서는 고객만족 회의를 통해 추 후 반영되어야 할 고객 의견과 추진 방향을 도 출한다. 고객만족 회의를 거치면서 개선되어야 할 프로세스가 확인되고 각부서와 조직에서 공 유하는 과정을 거친다. 필요에 따라서 서비스 교육이 병행되며. 서비스 교육은 현장 고객의 불만사항과 의견에 기초를 두고 이루어진다. 서 비스 교육은 공유된 아이디어가 원활하게 차별 화된 서비스로 전환되는 역할을 하게 된다.

그러므로 고객 의견의 수렴은 차별화된 서비 스를 제공하기 위한 출발점이 된다. 현장에서 의 고객 의견 접수는 물론 $\mathrm{VOC}$ 시스템에 의 해 고객 의견의 수렴과 정보구축은 체계화된

〈그림 4〉 고객의견 수렴 및 서비스 개선 프로세스

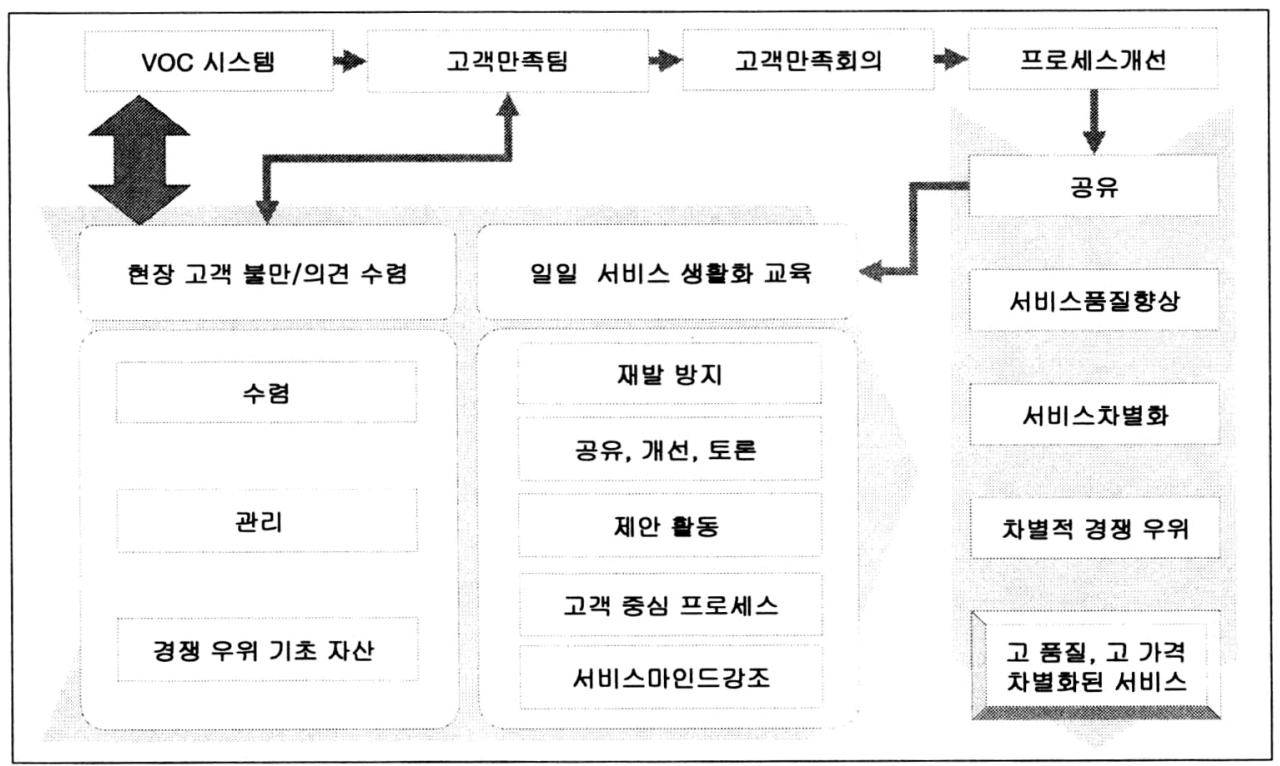


다. $\mathrm{VOC}$ 시스템에서는 다양한 정보채널을 활 용하고 있다. 서비스 제공 조직들과 자주 접속 하는 과정에서 관심사항을 주의 깊게 관찰함으 로써 이를 파악하고 있다. 이 시스템은 고객옥 구의 파악에 활용되며 파악된 불평이나 문제점 은 24시간 이내에 조치를 취하도록 되어 있으 며, 최고경영진에게 즉시 보고되며. 고객만족회 의를 거쳐 프로세스개선의 자료로 추후에 활용 된다. 작성된 자료는 전사적으로 공유하는 체계 를 갖추고 있다(〈그림 4〉참고).

고객 의견 중 칭찬과 불평에 대한 부분은 추 가적으로 관리과정을 거친다. 예를 들어 고객불 평 사례에 대해서는 주간사례토론회를 거친다. 칭찬과 불만 사례를 한 주에 한 개 선정하여 전 사업장 별로 토론을 거쳐 문제를 해결 방안 에 대해 토의하는 방식이다. 토의의 결과는 온 라인으로 등록하여 의견이 공유 되도록 하고 있다.

\subsection{3 고객관계 프로그램(서비스 포인트 제도)}

장기적인 관계에서 고객과 거래하는 것은 기 업이나 고객에게 장점이 있다. 고객은 자신의 옥구에 맞는 서비스를 제공받을 가능성이 높아 지며, 기업이 제공하는 포인트 제도에 따라 경 제적인 이익을 얻을 수도 있다. 기업입장에서는 신규고객의 확보를 위한 노력을 줄일 수 있으 며, 안정적으로 고객을 관리할 수 있다는 점에 서 장점이 있다. 결국 기업은 고객의 정보도 확 보하며 고객을 조직화한다는 측면에서 포인트 제도를 중심으로 한 고객 회원관리 프로그램을 운영하게 된다.

금호렌터카 역시 고객을 회원제로 관리하고 있다. 대여 횟수와 적립 포인트에 따라 회원 등 급을 구분하고 있다. 이용실적에 따라 5-10\%를 적립하도록 하였으며, 예약화면에서 회원의 포 인트를 확인할 수 있도록 하였다. 일반회원의

〈그림 5〉 다양한 VOC청취 시스탬

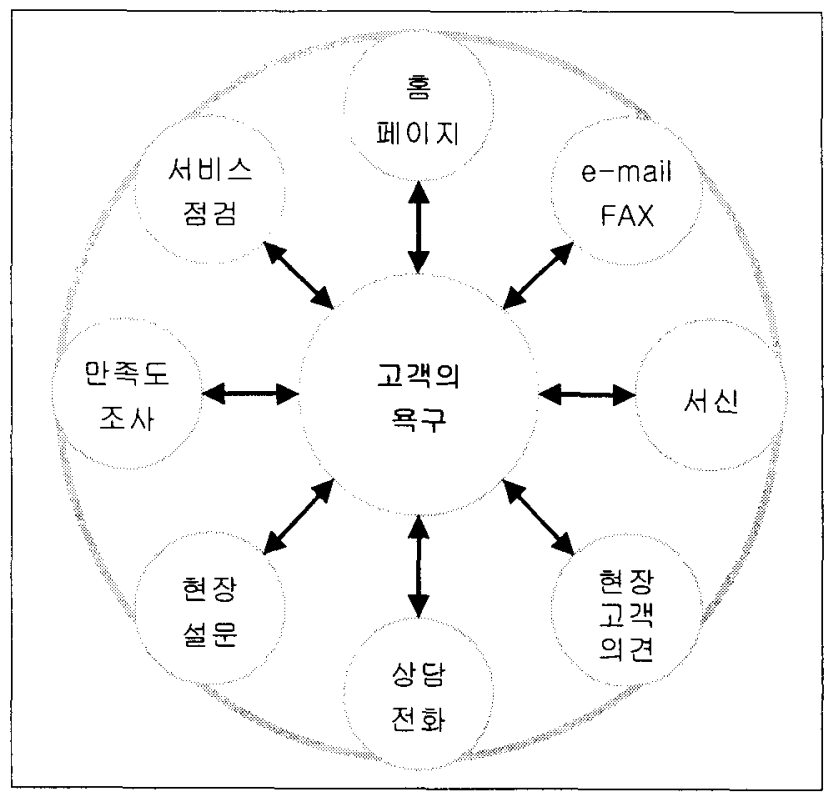


경우 가입 후 7회 이상이 경과하거나 정해진 적립규모에서 혜택을 받으며, 3 일 이상의 사용 에 대해서 배반차를 무료로 이용하고, 신차를 우선적으로 공급하고 지연반납에 대한 연체도 경우에 따라 면제하고 있다. 일반회원은 사용실 적이나 적립규모의 상승에 의해서 골드회원으 로 구분하여 보다 높은 할인율을 비롯한 많은 혜택을 부여한다. 일반회원의 증가는 물론 골드 회원의 증가하고 있어 장기적인 고객관계형성 이 진행되는 것으로 나타났다.

\section{4 고객만족을 위한 서비스 품질 향상 프로그램}

\subsection{1 서비스 제공자에 대한 포인트 제도의 운영}

서비스 제공자에게 포인트를 부여하는 제도는 서비스 품질을 유지하기 위해 시행하는 서비스 관리제도의 하나이다. 개인별 혹은 사업장 별로 서비스 실적에 따라 포인트를 부여하고, 포인트 가 기준치 이하로 내려갈 경우 서비스 클리닉 과정을 이수하게 하거나 해당하는 교육을 실시 하며, 기준치 이상을 넘어갈 경우 포상을 수여 한다. 이러한 제도의 도입을 통해서 공정하고 신뢰성 높은 고객만족서비스 활동의 평가가 가 능해 졌다. 서비스 품질이 향상되는 것을 기대
할 수 있음을 물론 금호렌터카 전 직원에 대해 서 고객만족을 위한 동기부여를 원활하게 하고 있기 때문이다. 이를 위해서 고객에게 제공된 서비스를 계량화하여 관리하여야 하며 서비스 모니터링은 지속적으로 진행되어야 한다.

\section{4 .2 고객 응대 서비스 프로세스}

금호렌터카에는 다양한 서비스 프로세스가 존 재한다. 대표적으로 고객응대 관점에서 배반차 응대표준이 정해져 있다. 우선 응대표준을 계약 서 작성시, 차량 준비 절차, 차량 반납시로 구 분하고 서비스 접점에 대한 세분화된 관리방침 을 정하고 있다. 계약서 작성은 예약관련 정보 의 확인, 고객 등록, 면허증 확인, 신용조회, 보 험업무, 차량 인도전 점검, 서명과 결제 등의 구체적 사안에 대해 표준과 절차를 명시화하고 있다. 차량 준비 절차 역시 세부적 사항에 대해 서 점검 기록과 지침을 보유하고 있다. 이는 차 량반납에서도 이어지는데 고객 응대를 위한 적 절한 인사법과 배웅절차도 규정하고 있다. 그러 므로 고객 응대 프로세스는 서비스의 품질을 통제하는 효과를 확보하고 있다. 물론 명확한 절차의 규정은 서비스 제공 시간을 통제하는 방안으로도 활용된다. 〈표 1〉에서는 금호렌터카 의 고객응대 프로세스가 수행되면서 소요되는 시간을 정리한 것이다. 이는 경쟁사에 대해서

〈표 1〉 고객응대 소요시간

\begin{tabular}{|c|c|c|c|c|}
\hline 구분 & 예약 & 배차 & 반차 & 계 \\
\hline Process time & 25초 & 12 분 & 2분15초 & \multirow{2}{*}{ 41분 25 초* } \\
\hline Lead time & 1분25초 & 25분 & 15분 (사고시) & \\
\hline
\end{tabular}

*경쟁사보다 10 분 이상 단축된 시간임 
우위에 있는 결과를 나타낸다.

\section{4 .3 순회정비 프로세스}

단기 대여 상품에서 배반차 응대 표준이 중요 하다면, 장기대여에서는 정비 서비스 프로세스 가 중요하게 관리되어야 한다. 고객이 원활하게 차량을 사용하기 위해서는 정비 서비스가 높은 수준으로 제공되어야 하며 이를 위해서 금호렌 터카는 순회정비 방식을 채택하고 있다. 그리고 순회 정비 서비스에 대해서도 프로세스를 관리 하고 있다. 즉 순회정비 정기 점검 항목에 대한 지속적 관리와 이에 대한 실적을 각 지점별 순 회 차량단위로 월별 관리를 한다(〈그림 6〉 참조).

금호렌터카의 서비스 프로세스는 결국 명확한
절차와 규정을 확보하고 준수에 대한 계량화를 통해서 서비스를 통제하는 것을 목적으로 한다.

\section{5 고객만족 경영을 위한 인적자원 및 조직구성}

이상에서 금호렌터카의 고객만족경영을 고객 관계관리와 서비스 품질개선 측면예서 살펴보 았다. 이하에서는 고객만족경영이 가능할 수 있 는 금호렌터카의 조직체계에 대해서 검토하고 자 한다. 포괄적으로는 최고경영층의 의지에서 구체적으로 인적 자원에 대한 교육프로그램에 이르기까지 인적자원의 활용과 조직의 구성체 계가 고객만족경영을 이루어내는 역할을 검토 한다.

〈그림 6〉 순회정비 프로세스와 조직별 서비스 통제 역할

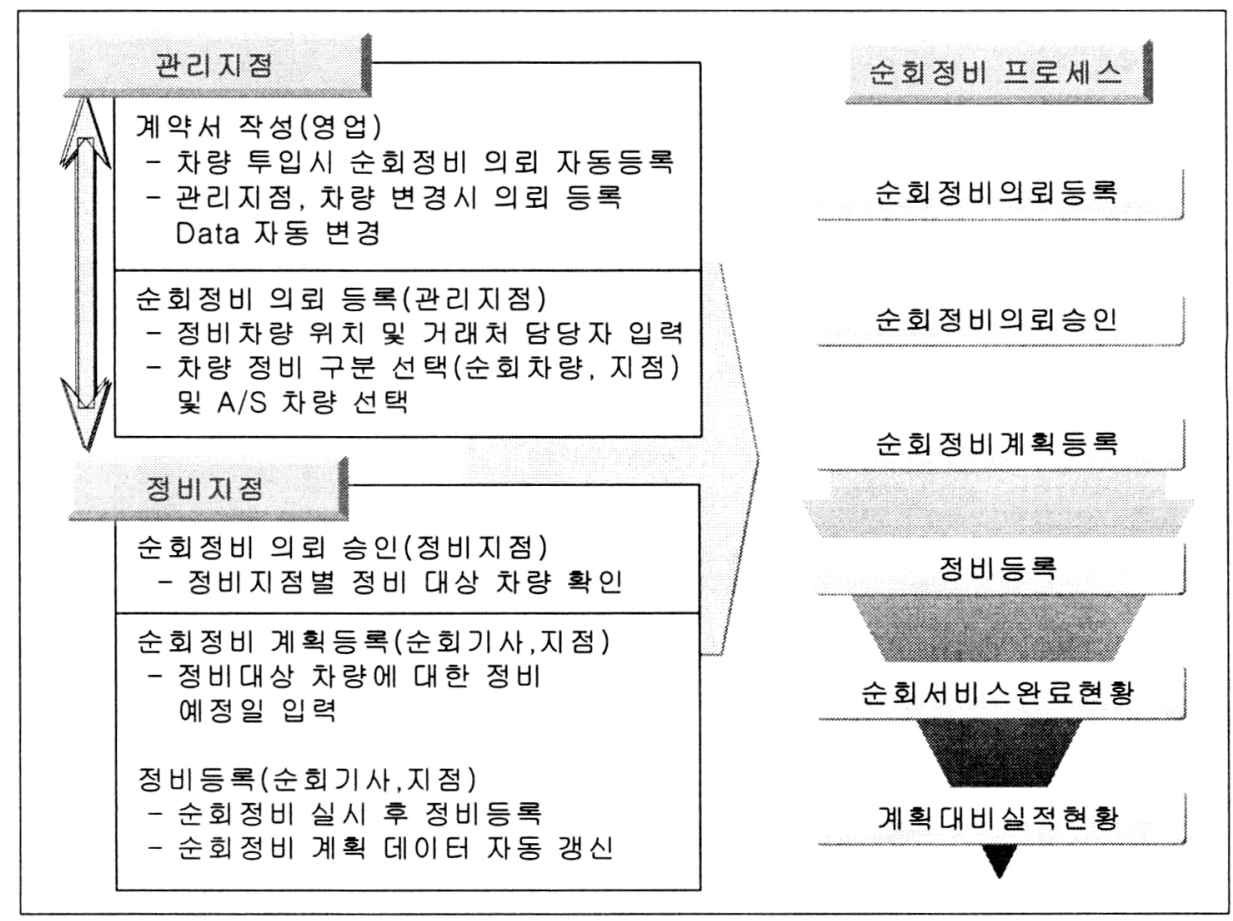




\subsection{1 최고경영충의 의지}

금호렌터카의 최고경영층은 네 가지의 경영자 리더십을 강조하고 있다. 이는 고객중심, 윤리 경영 실천, 창의적 전문 인력 양성, 그리고 솔 선수범하는 실천의지이다. 이중에서 고객중심은 금호렌터카의 고객만족 경영의 구현방식에 영 향을 미치고 있다. 경영자의 입장에서 조직구성 원이 공유해야 할 고객중심의 이넘을 구체화하 고 전달하고 있다. 그러므로 최고경영자의 '나 의 다짐'은 '금호렌터카의 다짐'으로 확대되어 있다.

금호렌터카의 다짐의 문구를 살펴보면 고객입 장에서의 고려, 고객의견의 자발적 경청, 고객
의 편안과 행복의 중요성을 강조하고 있다. 이 처럼 최고경영층의 고객만족 경영에 대한 의지 는 조직전반에 전파되어 있는데 프로세스의 개 선과 전사적 공유 체계의 구현을 통해서 이를 강화하고 있기 때문이다. 결국 최고경영층의 고 객만족에 대한 의지는 여타의 서비스 개선프로 그램 고객관계관리 프로그램과 융합되어 경쟁 력 제고방안으로 활용되고 있다(〈그림 7〉 참조).

\section{5 .2 내부 만족도와 1인당 생산성}

고객만족도를 위해서는 내부 구성원의 높은 만족수준이 요구된다. 금호렌터카에서는 Employœ Engagement Index를 활용하여 구성원들이 회

〈그림 7〉 최고경영자를 중심으로 한 프로세스 개선

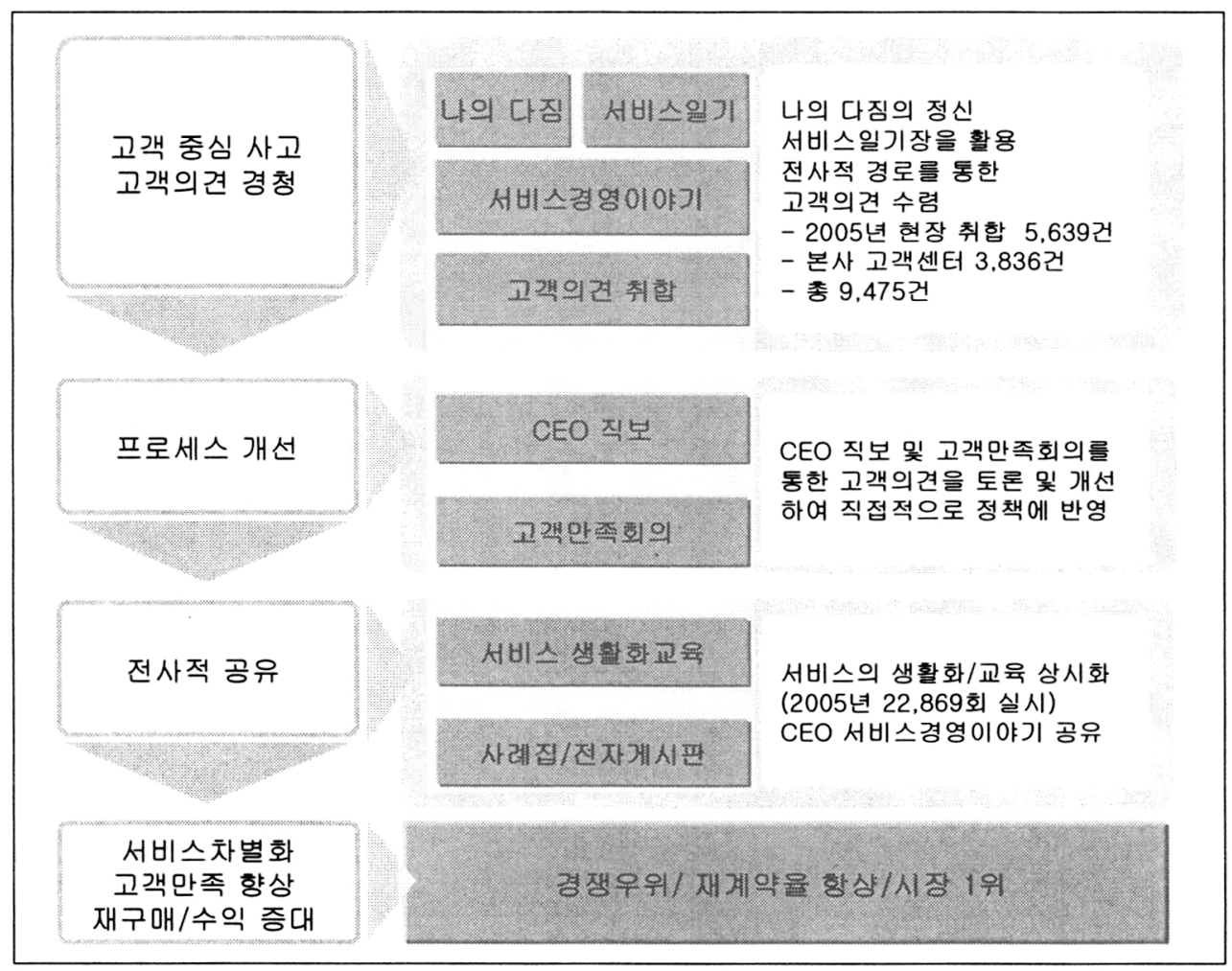


사의 성과 향상을 위해서 지적으로나 정서적으 로 조직에 관여하는 정도를 측정하고 있다. $\mathrm{EEI}$ 를 긍정적이라고 평가한 직원의 수를 비중 으로 환산할 때 $64 \%$ 를 기록하면서 전년대비 증가율도 평균 $40 \%$ 를 상회하고 있다. 이리한 결과는 내부구성원의 만족도를 위한 직원대상 설문조사, 부문 간 워크샵, 동아리 활동 활성화. 멘토링 제도, 조직인사 부문의 비전제시, 복리 후생제도의 개선, 그리고 포상제도의 도입 등이 작용한 것으로 분석된다. 내부 구성원의 만족도 가 꾸준히 상승하며서 1 인당 생산성의 증가도 눈에 띄게 상승하였다. 2006년 현재 1인당 생산 성이 7 억 8천 만원에 육박했다.

\subsection{3 서비스 아카데미}

서비스 강화를 위해서 서비스 아카데미를 운 영하고 있다. 고객만족의 중요성 인식에 따른 대고객 서비스 마인드 제고가 절실하게 필요하
며, 고객만족을 실현하기 위한 문제해결능력의 배양이 필요하기 때문이다. 무엇보다도 구성원 의 행동변화를 통한 고객만족도의 제고라는 차 원에서 교육을 강화하고 있다. 2006년도의 경우 교육을 받은 인원수 규모로 2,900 명에 가까운 인원이 교육을 받았으며 이를 시간으로 계산하 면 35,000시간에 육박한다(〈그림 8〉 참조).

\section{6 고객만족을 위한 향후 추진 전략}

금호렌터카는 고객만족을 위해 맞춤형 마케팅 전략과 차별화된 부가서비스 도입전략을 추구 하고 있다. 두 가지 전략은 고객의 의견을 수렴 하여 추후 집중적으로 강화할 서비스 프로그램 이다. 맞춤형 마케팅 전략을 위해서는 회원고객 에 따른 세분화가 요구된다. 고객 포트폴리오를 구성해서 고객을 관리한다는 점에서 관계관리 의 연장이라고 할 수 있다.

차별화된 부가 서비스도입전략을 위해서는 고

〈그림 8〉서비스 아카데미 프로그램

\begin{tabular}{|c|c|c|}
\hline 구 분 & 수행업무 & 세부 진행내역 \\
\hline 담당임원 & 총괄관리 & 회사 전반의 서비스활동 진단 \\
\hline $\begin{array}{l}\text { 고객만족팀 } \\
\text { 경영지원팀 }\end{array}$ & $\begin{array}{l}\text { 상벌규정 } \\
\text { 인사규정 }\end{array}$ & $\begin{array}{l}\text { 서비스의 상벌제도 운영 } \\
\text { 서비스 실적 등을 인사에 반영 }\end{array}$ \\
\hline 고객만족팀 & $\begin{array}{c}\text { 서비스교육 } \\
\text { 모니터링 } \\
\text { 아카데미 운영 } \\
\text { 서비스 클리닉 }\end{array}$ & $\begin{array}{l}\text { 교육에 대한 기본사항을 결정 } \\
\text { 교육일정,내용,강사투입 및 교육진행을 전담 } \\
\text { 교육 프로그램의 기획과 운영 이력관리,평가반영 } \\
\text { 현장지도 및 서비스 모니터링 실행 } \\
\text { 서비스 사내강사 운영 }\end{array}$ \\
\hline
\end{tabular}


〈그림 9〉 고객만족경영을 위한 금호렌터카의 향후 전략

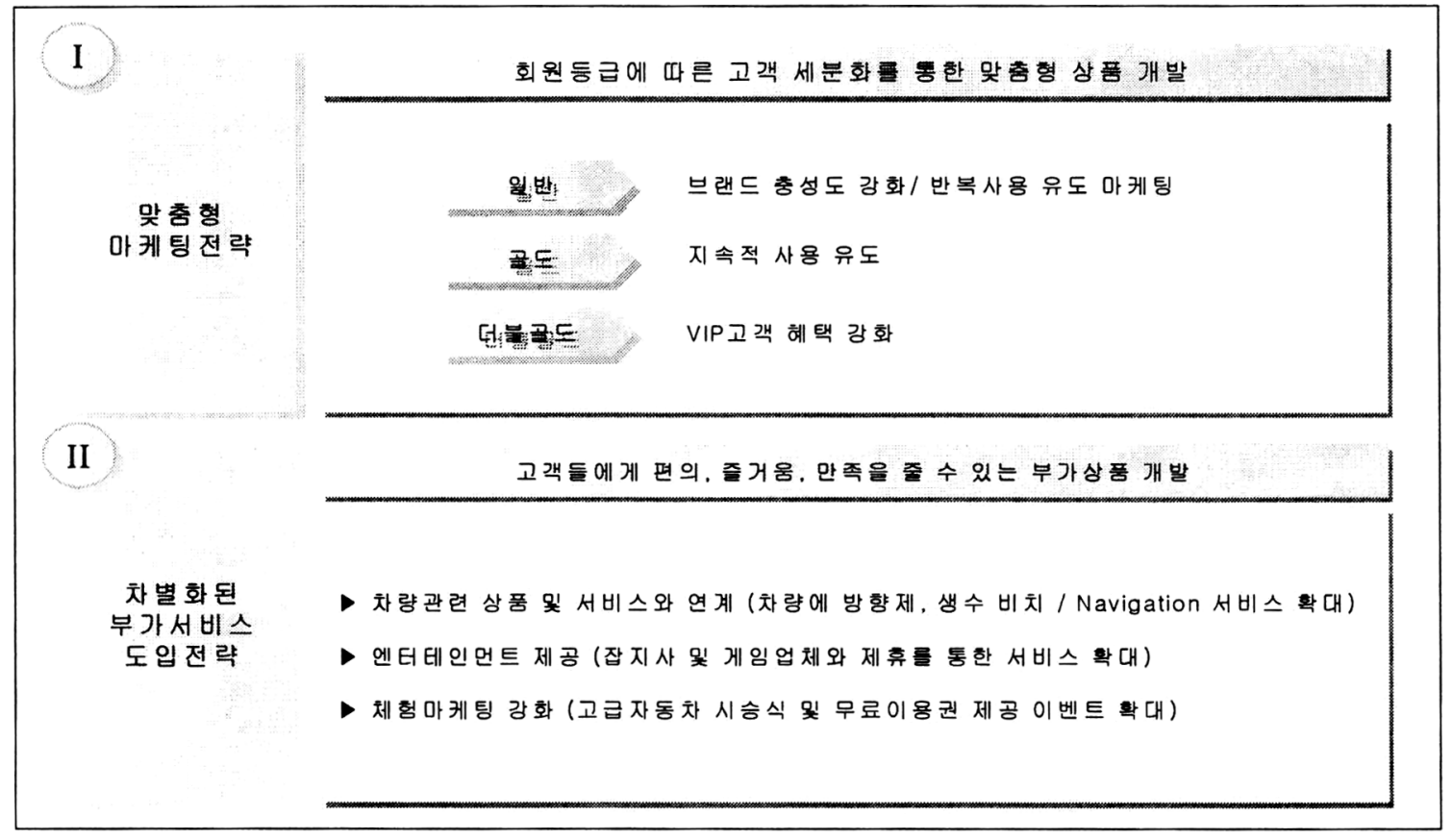

객의 편의, 만족, 그리고 즐거움을 제공할 수 있는 요소의 확인이 필요하다. 고객 의견의 수 럼절차에 따라 고객 중심에서 개발될 서비스 개념이며 품질관리의 측면에서 중요성이 높다. 구체적인 대안으로는 차량 관련 상품과 연계된 서비스의 제공, 오락적 요소의 강화, 체험마케 텅의 활용 등을 고려하고 있다(〈그림 9〉 참조).

\section{V. 결 론}

본 사례는 국내 렌터카 시장에서 시장점유율 과 매출액에서 최고의 위치에 있는 금호렌터카 의 성공요인에 대해 분석하였다. 금호렌터카가 렌터카 시장에서 대표기업으로 부상한 주요 성
공요인은 고객만족을 중시하는 경영에 있음에 주목하여 금호렌터카의 고객만족 경영방식을 상세히 고찰하였다.

본 사례에서는 금호렌터카의 고객만족 경영을 첫째, 고객의 욕구를 파악하는 것을 중심으로 한 고객관계관리 측면과, 둘째 서비스 품질통제 를 위한 서비스 프로세스 관리의 측면으로 나 누어 살펴보았다. 아울러 고객만족경영를 실행 하는 조직문화적인 측면에서 인적자원의 관리 와 고객만족경영 달성을 위한 최고경영층의 의 지를 분석하였다.

본 사례를 통해 기업경영에서 고객의 소리에 귀를 기울이고 고객의 욕구를 충족시킴으로서 고객만족 수준을 제고시키는 고객만족경영의 중요성을 다시 한 번 확인할 수 있었다. 아울러 고객만족경영은 단순히 추상적인 구호로 그쳐 
서는 그 효과를 발휘할 수 없으며, 금호렌터카 의 사례에서 볼 수 있듯이 구체적인 제도와 명 시된 프로세스를 갖추고 실행되어야 한다는 점 이 시사점으로 파악되었다. 이러한 고객만족경 영의 성공을 위해 최고경영층의 확고한 의지는 필수조건이며, 조직구성원들에게 고객만족경영 방식을 내재화 시키는 동기부여제도와 조직문 화의 중요성도 간과할 수 없다는 점도 중요한 시사점이다.

〈논문 접수일: 2007. 09. 30〉 〈게재 확정일: 2007. 09. 30〉

\section{참고문헌}

강부식, 김태한, 박상찬(2001), “QFD와 $\mathrm{QBD}$ 를 이용한 고객만족 전략 수립 절차에 관한 연 구," 품질혁신, 2(2), 1-7.

서창적, 김재환(2002), "종합적 품질경영 $(\mathrm{TQM})$ 의 종업원 몰입요인이 성과에 미치는 영 향," 경 영학연구, 31(3), 621-654. 이유재(2000), "고객만족경영의 개념과 실천에 관한 연구," 경영저널, 1(1), 153-172.

Anderson, Eugene W., Claes Fornell, and Sanal K. Mazvancheryl(2004), "Customer Satisfaction and Shareholder Value," Journal of Marketing, 68(4), 172-85.

Baron, Robert A.(2000), "Psychological perspectives on entrepreneurship: Cognitive and social factors in entrepreneurs' success," Current Directions in Psychological Science, 9(1), 15-18.
Berger, Paul D. and Nada I. Nasr(1998), "Customer lifetime value: Marketing models and applications," Journal of Interactive Marketing, 12(1), 17-30.

Dijkstra, Lieuwe and Hans van der Bij(2002), "Quality function deployment in healthcare: Methods for meeting customer requirements in redesign and renewal," International Journal of Quality \& Reliability Management, 19(1), 67-89.

Flynn, Barbara B., Sadao Sakakibara, and Roger G. Schroeder(1994), “A framework for quality management research and associated measurement instrument," Journal of Operations Management, 11(4), 339-366. Fornell, Claes(1992), "A National Customer Satisfaction Barometer: The Swedish Experience," Journal of Marketing, 56(1), 1-21.

Fornell, Claes, Sunil Mithas, Forrest V. Morgeson III, and M. S. Krishnan(2006), “Customer Satisfaction and Stock Prices: High Returns, Low Risk," Journal of Marketing, 70(1), 3-14.

Gruca, Thomas S. and Lopo L. Rego(2005), "Customer Satisfaction, Cash Flow, and Shareholder Value," Journal of Marketing, 69(3), 115-30.

Haenlein, Michael, Andreas M. Kaplan, and Detlef Schoder(2006), "Valuing the Real Option of Abandoning Unprofitable Customers When Calculating Customer Lifetime Value," Journal of Marketing, 70(3), 5-20. Kanj̈, Gopal K.(1998), "Measurement of Business 
Excellence," Total Quality Management, 9, 633-643.

Peppers, Don and Martha Rogers(1995). "Do You Want to Keep Your Customers Forever?" Harvard Business Review, 73(2), 103-114. Piercy, Nigel F.(1998). "Barriers to Implementing Relationship Marketing: Analysing the Internal Market-Place," Journal of Strategic Marketing, 6(3), 209-222.

Sheth. Jagdish N. and Atul Parvatiyar(1995), "Relationship Marketing in Consumer Markets: Antecedents and Consequences," Journal of academy of Marketing Science, 23(4), 255-271. 